\title{
Strategic trade policy with socially concerned firms
}

\author{
Luciano Fanti ${ }^{1}$ • Domenico Buccella ${ }^{2}$ D
}

Received: 16 October 2019 / Accepted: 24 January 2020 / Published online: 11 February 2020

(c) The Author(s) 2020

\begin{abstract}
In the light of the recent adoption of social responsible activities by large exporters, this paper sets up a strategic trade policy model in which two national champions compete à la Cournot in a third country and both governments can tax or subsidise the production of its local champion and reconsiders the well-known result of the Prisoner's Dilemma game structure in which governments set subsidies for their exporters. We show that (1) multiple sub-game perfect equilibria emerge in which one government taxes, while the other one allows free trade, provided that firms' social concerns are sufficiently large and (2) the social welfare of both countries in the latter asymmetric equilibrium is higher than that under free trade. Our findings suggest that a free-trade regime is always the less efficient policy in industries characterised by large social concerns. Moreover, we analyse the impact of the firms' social concerns interacting with strategic trade policies on welfare effects, showing that the welfares of consumers and the world as a whole (resp., total welfare of producing countries) are a U-shaped (resp., an inverted U-shaped) function of the intensity of social concerns: this suggests that in some cases, rather unexpectedly, producing countries (resp. consumers) benefit (resp. are harmed) by raising firms' social concerns.
\end{abstract}

Keywords Export subsidy $\cdot$ Prisoner's dilemma $\cdot$ Sub-game-perfect Nash equilibrium $\cdot$ Corporate social responsibility $\cdot$ Cournot duopoly

JEL Classification F16 $\cdot$ L13 $\cdot$ M14

$\triangle$ Domenico Buccella

buccella@kozminski.edu.pl

Luciano Fanti

Luciano.fanti@unipi.it

1 Department of Economics and Management, University of Pisa, Via Cosimo Ridolfi, 10, 56124 Pisa, PI, Italy

2 Department of Economics, Kozminski University, Jagiellońska Street, 57/59, 03301 Warsaw, Poland 


\section{Introduction}

A long-lasting and influential tenet in the theory of strategic trade policy is that the use of export subsidies allows to shift more of the oligopolistic profits towards one's own country. This belief dates back to the pioneering contributions of Brander and Spencer (e.g. 1984a, b, 1985) and is standard in current international trade's textbooks. Among the several surveys of this literature, we mention Grossman and Richardson (1985), Krugman (1986), Dixit (1987), Helpman and Krugman (1989) and Brander (1995). The essential features of the Brander and Spencer's models can be resumed as follows. There is an industry with one firm in each of two countries which compete on quantities (Cournot) in a third market. In such an industry, each firm would aim to convince the rival that it is producing a larger quantity, forcing the latter to reduce its production; in other words, it would act as the Stackelberg leader to raise its profit at the expense of the rival. However, to be really convincing, one firm should be able to commit itself to the threatened larger production. A government's export subsidy policy provides the "commitment" that the national firm exports more in the third market. In essence, a subsidy policy secures the profit shift in favour of the national firm, and if this shift more than counterbalances the cost of subsidy, then the subsidy policy improves the national welfare. ${ }^{1}$ On the other hand, the government's commitment to the policy instruments cannot always be taken for granted. In other words, if the government lacks that commitment, the timing of the game will be different so firms will move first anticipating (eliciting) the government reaction in the form of tax or subsidy, as in the pioneering work of Carmichael (1987) (see also Leahy and Neary 1997; Neary and Leahy 2000; Baghdasaryan and Žigić 2010; and the review paper by Žigić 2011).

The subsidy policy, however, presents the drawback that it lowers the total profits, in the sense that the aggressive behaviour produces a gain for the aggressor lower than the loss inflicted to the aggrieved, inducing a unilateral incentive to be aggressive. In terms of a game-theoretic approach, it means that when the governments of the exporting countries are interventionist in subsidising exports to third countries, a Prisoners' Dilemma emerges, and both lose. By contrast, it is known by Eaton and Grossman (1986) that with price competition, both countries can gain when one of them follows the strategic policy of taxing exports in order to restrain the production and thus to maintain high prices. ${ }^{2}$

In any case, an important element of the strategic trade policy identifies the types and characteristics of industries to be targeted with the subsidy policy instrument, because the "identification of these characteristics is a preliminary step toward translating theory into practical policy proposals" (Spencer 1986, 70-71).

\footnotetext{
${ }^{1}$ Notice that the benefits of the subsidy policy are magnified in the case of increasing returns (decreasing marginal costs), as Krugman (1984) shows in a model in which firms compete simultaneously in several segmented markets with declining marginal costs. This is because, on the one hand, the increase in the national firm's output induced by the subsidy reduces its marginal costs and, thus, further increases its aggressiveness; on the other hand, the corresponding reduction of foreign firm's output rises the marginal costs of the foreign firm, so that the latter firm is further disadvantaged.

${ }^{2}$ However, Etro (2011) shows that, contrary to the ambiguous results of strategic trade policy for duopolies, it is always optimal to subsidise exports when entry is endogenous, under both quantity and price competition.
} 
While the pioneering academic literature on the strategic trade policy dates back to the 1980s, in recent years, it has known a renewed interest, also in the light of the resurgence of the rhetoric and debate on the new governments' interventionism by the main actors in international trade to mitigate the effects of globalisation on national economies (see, for example, Scott and Glass 2016). Recent contributions have analysed how (1) the presence of cross-ownership (Fanti and Buccella 2016a); (2) different bargaining agendas in unionised labour markets (Bandyopadhyay and Bandyopadhyay 1998, 1999, 2001; Bandyopadhyay et al. 2000; Fanti and Buccella 2016b); and (3) the presence of managerial delegation (Fanti and Buccella 2017a) affect the strategic trade policy. However, in recent years, industries with new characteristics such as the presence of socially concerned firms appeared in various countries. In this work, we precisely focus on the firms' adoption of corporate social responsibility (hereafter, CSR) rules. Since the pioneering "paper is built around what seems to us an important part of the modern international environment" according to the words of Brander and Spencer (1984b, 19), we believe that the extension of their framework to another important part of the modern international environment which is currently represented by firms' CSR behaviours is worthwhile and in the spirit of the original literature. Indeed, Campbell et al. (2012) argued that "little research has been done on the motivations, either strategic or altruistic, behind CSR by Multinational Enterprises in host countries".

According to KPMG, the adoption of CSR behaviours is a prevailing worldwide business practice. In fact, 73 per cent of the top 100 companies surveyed in 45 countries in 2015 have reported the completion of CSR activities, with an increase of 9 percentage points with respect to 2011, when 64 per cent of the companies surveyed issued CRS reports. In addition, 92 per cent of the world's 250 largest companies indexed in the 250 Global Fortune Index have performed CSR actions, among them widely recognised giant exporters such as Volkswagen Group, Samsung Electronics, Apple, GM, BMW, Ford, Nestlé, Microsoft, Procter \& Gamble, CocaCola (KPMG 2011, 2015; Fortune 2015).

As a consequence, it is interesting to investigate whether CSR is a valid characteristic for targeting with subsidy policies an industry. In particular, we question whether the firms' social responsibility has relevant effects on the social welfare outcomes of the strategic trade policy above discussed. This assumes particular relevance because the firms' social responsibility is commonly perceived as a factor of welfare improvement, at least for the countries in which consumers are located.

In the present context, we consider the so-called consumers' friendly CSR which measures the firm's (and, therefore, supply-side) social interests through the inclusion of the consumer surplus in the firm's objective function to be maximised. The rationale for the adoption of this approach is because "consumers (beside shareholders) emerge as the most important stakeholder group when it comes to having an impact on a firm's approach to sustainability" (Kopel 2015). ${ }^{3}$

\footnotetext{
${ }^{3}$ However, there are different approaches to the modelling of CSR. Indeed, Manasakis et al. (2014) assumed that consumers highly evaluate the firm's social concerns, and this increases their demand. In other words, the firms' socially responsible attributes are attached to products that consumers view as
} 
The research on CSR firms has been mainly carried out on the aspects of private provision of public goods and private elimination of a public bad (Bagnoli and Watts 2003; Kotchen 2006; Besley and Ghatak 2007), and the motives that lead companies to be socially responsible (Baron 2001, 2009; Porter and Kramer 2006; Benabou and Tirole 2010; Lambertini and Tampieri 2012, 2015; Kopel and Brand 2012). In an appropriate game-theoretic context, Fanti and Buccella (2017b) have analysed the firms' strategic decision of adopting CSR behaviours; however, those authors consider only firms that operate in a domestic market context, while they abstract from issues related to international trade in the presence of governments' strategic policies. In an international trade context, Wang et al. (2012), Chang et al. (2014) and Chao et al. (2016) studied the impact of the domestic firm and foreign exporter's CSR behaviours on the government's optimal tariff application in an import competing model. However, none of them deals with the issue of the export tax/subsidy policy within the Brander and Spencer's frame, developed when the adoption of firms' CSR behaviours was not a widespread phenomenon as nowadays.

This paper contributes to the literature on CSR by investigating the so far unexplored interconnections with strategic trade policy. It revisits the cornerstone model of the strategic trade policy literature at the light of the increasing diffusion of social interests by firms.

To analyse the impact of the firms' social responsibility on social welfare and the interactions with the strategic trade policy, we propose a three-stage game characterised by the following timing. In the pre-play stage, governments choose whether to implement the trade policy. In the first stage, the exporting countries' governments set the optimal subsidy (tax) to maximise their own welfare, given by the exporter firm's profits minus (plus) the subsidy spending (tax revenue). Finally, in the second stage, the firms simultaneously and independently choose their output: that is, we assume that firms choose production levels following their respective governments' commitment to trade policy decisions. We apply the backward induction method because the solution concept adopted is the Sub-game perfect Nash equilibrium (SPNE).

The main results of the paper are as follows. First, while the received literature on CSR firms (at least in the basic Cournot model) mainly considers that consumers and social welfares (resp. profits) are always increasing (resp. decreasing) in the weight of the social concern assigned by the firm in its objective function, we show that the interaction of the firms' social concerns with the strategic trade policy produces "mixed" rather than univocal results on the social welfare and its components. Second, given that the objectives of the firm and the government are no longer aligned because the exporting firm now cares also about consumers in the third country, it may happen that the firm produces more than a Stackelberg leader.

Footnote 3 (continued)

credence goods and form expectations about their existence and level. In this sense, CSR can be often referred to behaviour such as "fair trade" production: consumers of fair trade coffee, for example, receive a warm glow from the knowledge that coffee growers are receiving a higher price than they otherwise might. Also, this alternative formulation for modelling CSR behaviours is worth to be explored and it is left for future research. 
Therefore, we show that the presence of socially concerned firms, on one hand, alters the selection of the policy instrument (which may be shifted from a subsidy to a tax when firms' social concerns are sufficiently intense to discourage excessive, profit-reducing production) and, on the other hand, generates a rich variety of SPNE equilibria as well as their efficiency properties. In particular, with regard to the emergence of endogenous equilibria, we show that a shift from the interventionist regime in both countries (as in the traditional model) to an asymmetric SPNE (in which the prisoners' dilemma situation does not materialise anymore) can be generated by adequately high firms' social concerns. The rationale for this result is as follows: if one country taxes its champion, it reduces also aggregate output such that the other country will benefit and decide not to pursue any strategic trade policy. More interestingly, this asymmetric equilibrium always Pareto dominates the freetrade regime. Moreover, in order to check the robustness of the results above mentioned, we have endogenized the choice of the "optimal" CSR parameter by firms. In such a case, numerical simulations have shown that it is welfare-preferred to intervene with a small export tax. Under the endogenous CSR parameter's choice, we have also investigated the case in which the government lacks the commitment to the policy instruments, showing that in the game between governments, the results of the basic framework (two asymmetric equilibria in which the intervening government taxes export) are confirmed, but firms do not find profitable to engage in CSR (or, even, they find profitable to engage in the so-called CS Irresponsible activities).

It is worth noting that the game-theoretic approach proposed in this paper is the fundamental methodology for revealing the not straightforward effects of the interconnections between CSR in an industry and the strategic trade policy, because the "application of basic game theory is a feature of strategic trade policy that distinguishes it from much of the previous work in international economics" (Spencer and Brander 2008).

The remainder of the paper is organised as follows. Section 2 develops the model of strategic trade policy in the presence of CSR firms. Section 3 studies the governments' policy selection and derives the game equilibria. Section 4 discusses the welfare implications. Section 5 briefly discusses some extensions of the basic model. Finally, Sect. 6 closes the paper with an outline for future research.

\section{The model}

Following the classical Brander and Spencer (1985) work, we consider a model with two exporting countries, each with a firm. Both firms (1 and 2) produce homogeneous goods sold to a third, importing country in which are engaged in quantity (Cournot) competition.

We assume the following standard linear inverse market demand

$$
p=a-q_{i}-q_{j}
$$

where $p$ denotes price and $q_{i}$ and $q_{j}$ are the firms' output levels for $i, j=1,2$ and $i \neq j$. For tractability, the two firms are assumed to have zero production costs. 


\subsection{Under strategic trade policies}

Country 1 and 2's governments provide their producers with specific export subsidies, $s_{i} \in R$. Therefore, profits are given by

$$
\pi_{i}=\left(a-q_{i}-q_{j}+s_{i}\right) q_{i} .
$$

Following the recent established literature (e.g. Goering 2007, 2008; Kopel and Brand 2012; Lambertini and Tampieri 2012, 2015), we assume in our model that all the social concerns can be interpreted as part of consumer surplus. Therefore, the feature of a CSR firm is to take care of consumer welfare and in its objective function maximises profits plus a fraction of the market consumer surplus. In other words, we consider the so-called consumers' friendly CSR activities. The level of "social concern" $k$ is taken as exogenously given by the private owners in the case of CSR rules adoption, for instance, by the "customary toughness" of the stakeholders incorporated in the firm's objective function. Moreover, given that those firms export all their production, it seems natural to assume that companies take care of the consumers in their relevant (third) market. Consequently, the CSR firm's objective function can be simply specified as a parameterized combination of profits and consumer surplus of the relevant market. It follows that the CSR objective function $(W)$ is:

$$
W_{i}=\pi_{i}+k C S=\left(a-q_{i}-q_{j}+s_{i}\right) q_{i}+k \frac{\left(q_{i}+q_{j}\right)^{2}}{2}
$$

where $k \in[0,1]$ denotes the weight that a CSR firm assigns to consumer surplus. ${ }^{4}$

The timing of the game is as follows. At the pre-play stage, governments decide on whether to intervene in trade policy. At the first stage, the governments of the exporting countries set the optimal subsidy/tax to maximise their own welfare (SW), which is given by the profit minus the cost of subsidisation:

$$
\mathrm{SW}_{i}=\pi_{i}-s_{i} q_{i}
$$

At the second stage, the firms simultaneously and independently choose their output. We solve the game in the usual backward induction fashion.

At stage 2, the analysis is carried as usual through the maximisation of (3) with respect to the quantity, obtaining the following reaction function

$$
q_{i}\left(q_{j}\right)=\frac{\left[a-(1-k) q_{j}+s_{i}\right]}{(2-k)} .
$$

\footnotetext{
${ }^{4}$ Goering $(2007,2008)$ considers the non-profit organisations (NPOs) which compete in commercial markets selling their output and services and thus generating revenues. This typology include, for example, sectors such as the high-tech markets (Benz 2005), water utility, rail track maintenance company, university bookstores (Schiff and Weisbrod 1991) and private air-traffic control organisation (Bennett et al. 2003).
} 
Solving the system of the two reaction functions, thus one gets the output as a function of subsidy rates

$$
q_{i}\left(s_{i}, s_{j}\right)=\frac{\left[a+s_{i}(2-k)-s_{j}(1-k)\right]}{(3-2 k)} .
$$

Substituting (6) in the profit equation and in the social welfare function (4), each government maximises social welfare with respect to its subsidy rate for a given subsidy rate of the other government. Thus, the following reaction function in subsidy rates is obtained:

$$
s_{i}\left(s_{j}\right)=\frac{a\left(2 k^{2}-5 k+1\right)-s_{j}}{2(2-k)}
$$

Solving the system of reaction functions (7), we obtain the equilibrium subsidy (tax) rates:

$$
s_{1}=s_{2}=s^{S, S}=\frac{a\left(2 k^{2}-5 k+1\right)}{(5-2 k)}
$$

where the superscript $S, S$ denotes that both exporting countries' governments implement strategic trade policy.

By substituting (8) backwards, after the usual algebra, the equilibrium values of output, profit and social welfare, which are symmetric for both exporting countries, are derived:

$$
\begin{gathered}
q^{S, S}=\frac{a(2-k)}{(5-2 k)} \\
\pi^{S, S}=\frac{a^{2}(1-2 k)(2-k)^{2}}{(5-2 k)^{2}} \\
S W^{S, S}=\frac{a^{2}(2-k)}{(5-2 k)}
\end{gathered}
$$

Moreover, consumer's surplus in the third market (CS) is

$$
\mathrm{CS}^{S, S}=2\left(\frac{a(2-k)}{5-2 k}\right)^{2}
$$

Finally, the total world welfare (WW), which is defined as the sum of the social welfare of the two exporter countries and the consumer's surplus in the third market, is

$$
\mathrm{WW}^{S, S}=\frac{2 a^{2}(2-k)(3-k)}{(5-2 k)^{2}}
$$




\subsection{Under free-trade regime}

In this case, there is only the stage in which firms compete in quantities.

The analysis is carried out as usual through the maximisation of (3) with respect to the quantity setting $s_{i}=0$, solving the system of the two reaction functions. Thus, one gets the equilibrium output in the case of free trade (FT)

$$
q^{\mathrm{FT}, \mathrm{FT}}=\frac{a}{3-2 k}
$$

Substituting this in the profits' equation, we obtain

$$
\pi^{\mathrm{FT}, \mathrm{FT}}=\frac{a^{2}(1-2 k)}{(3-2 k)^{2}} .
$$

Obviously, under free-trade, profits (15) also represent the exporting countries' social welfare, while consumer's surplus in the third market and world welfare are

$$
\begin{aligned}
& \mathrm{CS}^{\mathrm{FT}, \mathrm{FT}}=2\left(\frac{a}{3-2 k}\right)^{2} \\
& \mathrm{WW}^{\mathrm{FT}, \mathrm{FT}}=\frac{4 a^{2}(1-k)}{(3-2 k)^{2}}
\end{aligned}
$$

\subsection{Under unilateral strategic trade policy}

To determine the SPNE of the governments' game, we have to evaluate the pay-offs in the asymmetric case, in which one subsidises, while the other one allows free trade. We conventionally assume that government 1 subsidises, while government 2 does not intervene (that is, $s_{2}=0$ ). Standard calculations based on the opportunely modified (6)-(7), and the maximisation by government 1 of its social welfare lead to the following subsidy rate:

$$
s_{1}^{S, \mathrm{FT}}=\frac{a\left(2 k^{2}-5 k+1\right)}{2(2-k)} .
$$

By substituting backwards (18) (and $s_{2}=0$ ) in (6) and then in (2) and (4), we obtain the following output, profits and social welfares of countries 1 and 2:

$$
\begin{gathered}
q_{1}^{S, \mathrm{FT}}=\frac{a(1-k)}{2} \\
q_{2}^{S, \mathrm{FT}}=\frac{a\left(1+2 k-k^{2}\right)}{2(2-k)}
\end{gathered}
$$




$$
\begin{gathered}
\pi_{1}^{S, \mathrm{FT}}=\frac{a^{2}(1-k)\left(1+k^{2}-3 k\right)}{2(2-k)} \\
\pi_{2}^{S, \mathrm{FT}}=\frac{a^{2}(1-k)\left(1-k^{2}+2 k\right)}{4(2-k)^{2}} \\
\mathrm{SW}_{1}^{S, \mathrm{FT}}=\frac{a^{2}(1-k)^{2}}{4(2-k)} \\
\mathrm{SW}_{2}^{S, \mathrm{FT}}=\pi_{2}^{S, \mathrm{FT}} .
\end{gathered}
$$

Finally, consumer's surplus in the third market and world welfare are given by

$$
\begin{aligned}
\mathrm{CS}^{S, \mathrm{FT}} & =\frac{1}{8}\left(\frac{a(3-k)}{2-k}\right)^{2} \\
\mathrm{WW}^{S, \mathrm{FT}} & =\frac{2 a^{2}(2-k)(3-k)}{(5-2 k)^{2}}
\end{aligned}
$$

\section{The analysis of the strategic game played by national governments}

Preliminarily, we establish the following Lemmas.

Lemma 1 Nonnegativity constraints and second-order conditions are satisfied if $k \leq k^{\circ} \approx 0.382$ (that is, the firm's interest for the consumer's welfare has not to be too much high).

Proof see "Appendix".

This constraint will be satisfied throughout the paper.

Lemma 2 When both governments intervene, they set a subsidy (resp. a tax) if $k \leq$ (resp. $>$ ) $\quad k^{\circ \circ} \approx 0.219$. This holds true also when only one government unilaterally intervenes (while the other one abstains from intervening).

Proof The proof is straightforward from the observation of (8) and (18) and omitted here for brevity. ${ }^{5} \square$

\footnotetext{
${ }^{5}$ All analytical details of the proofs not reported in "Appendix" are available upon request from the authors.
} 
Table 1 Pay-offs matrix of the game between governments

\begin{tabular}{lll}
\hline & $\mathrm{FT}$ & $S$ \\
\hline $\mathrm{FT}$ & $\mathrm{SW}_{1}^{\mathrm{FT}, \mathrm{FT}}, \mathrm{SW}_{2}^{\mathrm{FT}, \mathrm{FT}}$ & $\mathrm{SW}_{1}^{\mathrm{FT}, S}, \mathrm{SW}_{2}^{\mathrm{FT}, S}$ \\
$S$ & $\mathrm{SW}_{1}^{S, \mathrm{FT}}, \mathrm{SW}_{2}^{S, \mathrm{FT}}$ & $\mathrm{SW}_{1}^{S, S}, \mathrm{SW}_{2}^{S, S}$ \\
\hline
\end{tabular}

In other words, the larger firms' social concerns, the more likely a tax instead of a subsidy is optimal. This lemma suggests that under a sufficiently intense CSR behaviour, the standard Brander and Spencer (1985)'s result about the type of chosen trade policy instrument is reversed.

An intuitive explanation of this result is as follows. In the standard Brander and Spencer (1985)'s approach, since governments set their subsidy policy before the two firms simultaneously choose their outputs, the subsidy allows the domestic firms to achieve the outcome that would obtain if they were able to act as a Stackelberg leader in the market stage. However, firms' social concerns imply that each firm is by itself producing more than the output under standard Cournot competition; then, if $k$ is too high, the optimal policy requires that output is dampened (instead of stimulated) to sustain prices and profits. We also observe that the sign of the subsidy is the same across unilateral and bilateral policies, but the subsidy is lower in absolute terms in case of unilateral policies. The reason for this result is that if the government of one country does not intervene, the interventionist government does not have to foster excessively the production of the national champion to let him gain market shares on the third market.

Now, we address the important issue of the endogenous determination of the equilibrium regime (i.e. the sub-game perfect Nash equilibrium, SPNE). The countries' benefits of the different policy regimes are summarised in the governments' pay-off matrix in Table 1. The strategies for each government are to be interventionist (tax/subsidy, S) or to adopt a non-interventionist stance (free trade, FT). As usual, the first element in each entry represents the pay-off of country 1, while the second element represents the country 2's pay-off. Along the top, government 2's strategies are listed, and along the left, government 1's strategies are represented. Let us define the following social welfare differentials:

$$
\Delta_{1}=S W_{1}^{S, \mathrm{FT}}-\mathrm{SW}^{\mathrm{FT}, \mathrm{FT}} ; \quad \Delta_{2}=\mathrm{SW}_{2}^{S, \mathrm{FT}}-\mathrm{SW}^{S, S} ; \quad \Delta_{3}=\mathrm{SW}^{S, S}-\mathrm{SW}^{\mathrm{FT}, \mathrm{FT}},
$$

and, in particular,

$$
\begin{aligned}
& \Delta_{1}=\frac{a^{2}\left(2 k^{2}-5 k+1\right)^{2}}{4(2-k)(2 k-3)^{2}}, \\
& \Delta_{2}=\frac{a^{2}\left(2 k^{2}-5 k+1\right)\left(2 k^{3}-11 k^{2}+18 k-7\right)}{4(2-k)^{2}(2 k-5)^{2}}, \\
& \Delta_{3}=\frac{a^{2}\left(2 k^{2}-5 k+1\right)(2 k-7)}{(2 k-5)^{2}(2 k-3)^{2}} .
\end{aligned}
$$

The first differential reveals when a government has an incentive to deviate from a free-trade regime and to become interventionist. The second differential identifies 
when a government has an incentive to deviate from a situation of mutual interventionism towards free trade. Finally, the third differential informs us about the Pareto efficiency properties of the equilibria. Their analytical inspection allows us to derive the next result with regard to the game equilibria.

Result 1 If $0 \leq k \leq k^{\circ \circ} \approx 0.219$, then $S, S$ is the SPNE of the game between governments. If $k^{\circ \circ}<k \leq k^{\circ}$, then two asymmetric SPNEs, in which one government taxes own export and the other government does not intervene, emerge.

Proof Since $\Delta_{1}>0$ and $\Delta_{2} \geq 0 \Leftrightarrow k \geq k_{<}^{\geq}$, Result 1 is proved. $\square$

This result shows that a sufficiently high CSR behaviour parameter drastically changes the traditional equilibrium regime.

The channels through which the "new" multiple equilibria appear are briefly explained as follows. First, we establish the relationship at equilibrium between, on the one hand, the policy instrument, output and profits, and on the other hand the level of CSR concerns:

Lemma 3 In the $(S, S)$ equilibrium:

(1) the CSR parameter, $k$, always reduces the optimal value of the trade policy parameter, $s^{S}$;

(2) although output for given policy parameters would be always increased, as expected, when consumer's surplus is taken into account (i.e. the higher the $k$, the higher the $q^{S}\left(s^{S}\right)$ ), it becomes reducing for $k$ increasing when also the reducing effect of $k$ on the policy parameter (see part 1 of this lemma) is considered;

(3) while, on one hand, the reduction of output is pro-collusive, on the other hand, the reduction of the policy parameter directly reduces profits: in the overall, profits are always reduced by an increasing CSR parameter $k$.

\section{Proof see "Appendix"}

Then, we have one counter-intuitive negative effect of CSR behaviours on output, but the reduction in output (i.e. the price increase) is not sufficient to increase profits because the reduction of the subsidy (or the increase of the tax) is more intense, so that also profits are definitively reducing (as shown in part (3) of lemma above) with CSR behaviours, as expected. Now, we show that:

Lemma 4 Despite the fact that CSR behaviours reduce profits of the exporter firm, the social welfare of the exporter countries under S,S increases with an increasing CSR parameter because the cost of subsidy (resp. tax revenue) is reduced (resp. increased) more than the profits reduction.

Proof see “Appendix". 
Lemma 5 Profits of the free trader (and thus also the social welfare) at the asymmetric regime are always increasing with CSR parameter, $k$.

Proof see "Appendix".

Note that the part (2) of Lemma 3 does not hold at the asymmetric regime because the quantity exported from the free-trader country is increasing with $k$, and thus, the effect of the latter on the profit is a priori ambiguous, as shown by the generic derivative in the proof of Lemma 5: however, the reducing effect on the output of the rival firm is prevailing and always able to increase profits (i.e. social welfare) of the free-trader country.

Finally, we show that, although both $\mathrm{SW}^{S, S}$ and $\mathrm{SW}_{2}^{S, F T}$ are increasing with $k$ (as shown by Lemmas 4 and 5 , respectively), $\mathrm{SW}_{2}^{S, \mathrm{FT}}$ increases more rapidly than $\mathrm{SW}^{S, S}$ so that a threshold level of $k$ above which the disadvantage to not retaliate to the unilateral subsidisation becomes an advantage (also because the policy of the rival country becomes a unilateral taxation) does necessarily exist and, as a consequence, the multiple asymmetric SPNE of Result 1 emerges.

Lemma 6 Given that

$$
\frac{\partial S W^{S}}{d k}-\frac{\partial S W_{2}^{S, F T}}{d k}=\frac{a^{2}\left(8 k^{6}-108 k^{5}+590 k^{4}-1657 k^{3}+2472 k^{2}-1767 k+404\right)}{4(5-2 k)^{3}(2-k)^{3}}<0,
$$

then, it is explained why $\Delta_{2} \geq 0 \Leftrightarrow k \geq k_{<}^{\circ \circ}$ occurs.

\section{Welfare analysis of SPNEs and the role played by CSR}

Now, after the above analysis of the SPNE of the game, a more detailed welfare analysis, which takes into account different regimes and different SPNEs when the firms' social concerns are present and increasing, is in order. In particular, we consider the welfare effects regarding (1) exporting countries, (2) third market country, (3) world as a whole.

\subsection{Social welfare in exporting countries}

Result 2 In contrast with the traditional result, both countries are better off in the $S$ equilibrium than under FT, provided that firms' social concerns are sufficiently intense, that is $k>k^{\circ \circ}=0.219$.

Proof Since $\Delta_{3} \geq 0 \Leftrightarrow k \geq k_{<} 0 \circ$, Result 2 easily follows. 


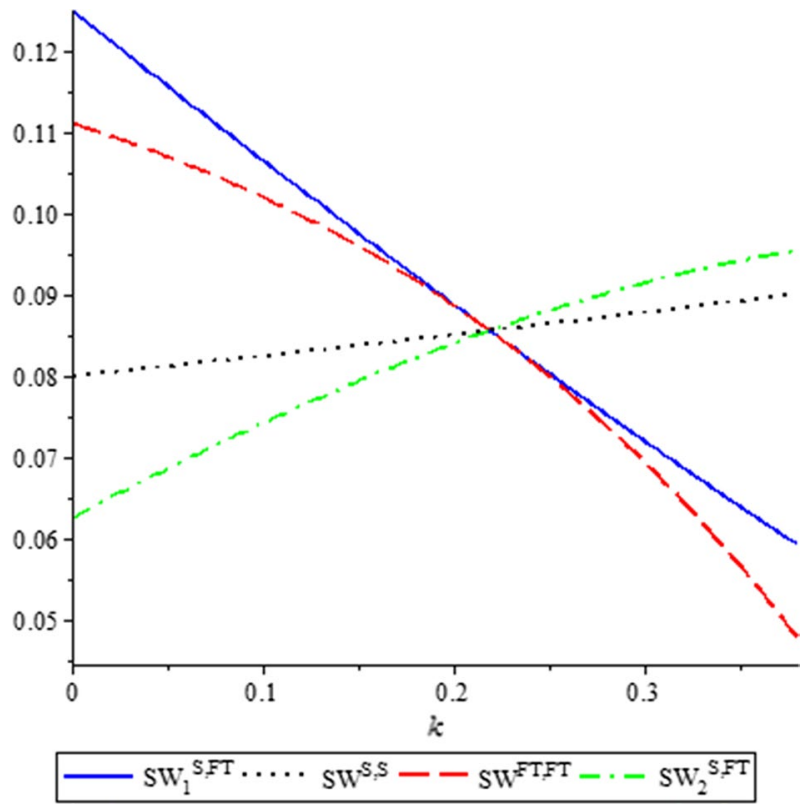

Fig. 1 Social welfare of each exporting country under different regimes: unique symmetric, S, (i.e. policy/policy, $(\mathrm{S}, \mathrm{S})$ ), and FT (i.e. free trade/free trade (FT,FT)), and multiple asymmetric, M, (i.e. policy/no policy $(\mathrm{S}, \mathrm{FT})$ or no policy/policy $(\mathrm{FT}, \mathrm{S})$ ), for a varying intensity of firms' social concerns (i.e. $0<k<0.382$ ). Legend: the graph is depicted for $a=1$.

Result 2 predicts that, for $k>k^{\circ \circ}$, a regime where both governments intervene would be better than the laissez-faire regime; however, as Result 1 shows, the SPNE when $k>k^{\circ \circ}$ is a multiple asymmetric one.

Therefore, while for $k<k^{\circ \circ}$, the structure of the Prisoner's dilemma of Brander and Spencer (1985) is confirmed, for $k>k^{\circ 0}$, the game becomes a coordination game with two asymmetric regimes (S/FT or FT/S) whose welfare's properties are so resumed:

Remark 1 For what concerns social welfare (1) for the country without trade policy, the regime S/FT is the best between the four regimes; (2) for the country with a tax trade policy, the regime S/FT is always better than the free-trade regime.

Interestingly, under the S/FT equilibrium, not only the welfare of the country without trade policy but also that of the country with an active trade policy is higher than in the case in which both countries choose free trade, that is, when $k>k^{\circ \circ}$, the common wisdom according to which the free-trade regime is welfare superior is reversed being such a regime the worst one, as shown in Fig. 1.

The economic intuition of Remark 1 is as follows: (1) for the free-trader country, the fact that the rival country is taxing allows for a support for the 


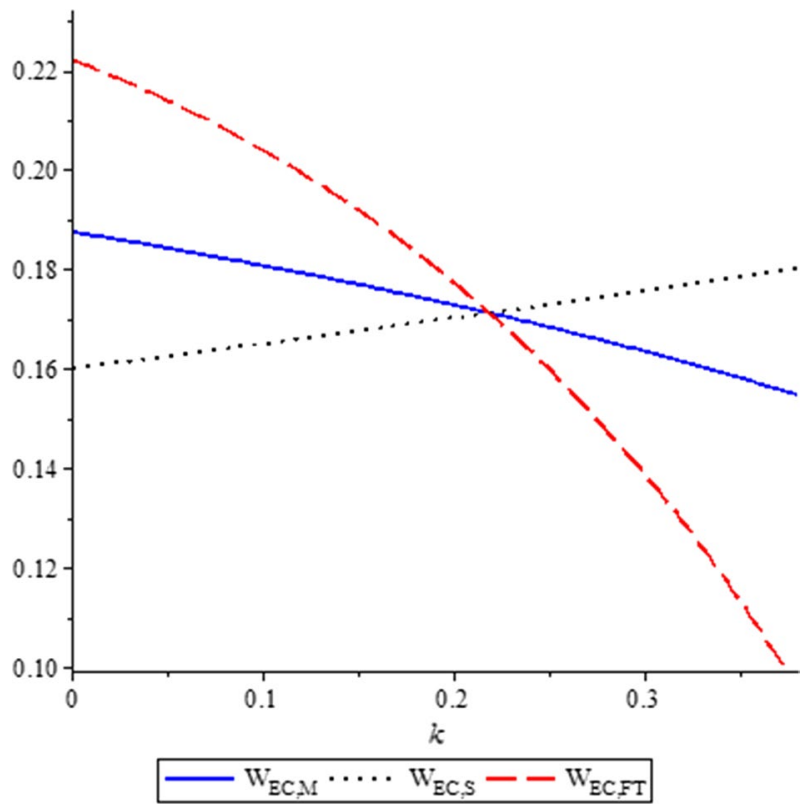

Fig. 2 Total welfare of exporting countries $\left(W_{\mathrm{EC}}\right)$ under different regimes: unique symmetric, $\mathrm{S}$ (i.e. policy/policy, $(\mathrm{S}, \mathrm{S})$ ), and FT (i.e. free trade/free trade (FT,FT)), and multiple asymmetric, M, (i.e. policy/no policy (S,FT) or no policy/policy $(\mathrm{FT}, \mathrm{S})$ ), for a varying intensity of firms' social concerns (i.e. $0<k<0.382$ ). Legend: the graph is depicted for $a=1$.

international price and an increase in its market share and thus is clearly the most favourable regime; (2) for the taxing country, although it would be better that also the other country would fix a tax instead of abstaining to tax, it is always convenient to tax its exported quantity notwithstanding that this, under Cournot competition, reduces its own export and increases that of the rival country, because the loss of the market share is more than counterbalanced by the tax revenue. Now, some considerations about the welfare effects due to the existence of CSR behaviours are in order here.

Remark 2 When both governments intervene, the sum of exporting countries' welfares is, as expected, increasing with $k$, while when only one government intervenes as well as under free trade is decreasing with $k$.

Remark 3 Taking into account the switch between the endogenous equilibrium regimes when firms' social concerns increase, the sum of exporting countries' welfares is an inverted U-shaped function of $k$, (see Fig. 3): exporter economies are ultimately harmed when their exporters are strongly socially responsible, but, rather unexpectedly, for a ample range of values of $k$ (i.e. for $0<k<0.32$ ), their total welfare is either increasing or at least superior than in the case of sole profit-seeking behaviour, when their exporter firms are "concerned" with the foreign consumers' surplus. 


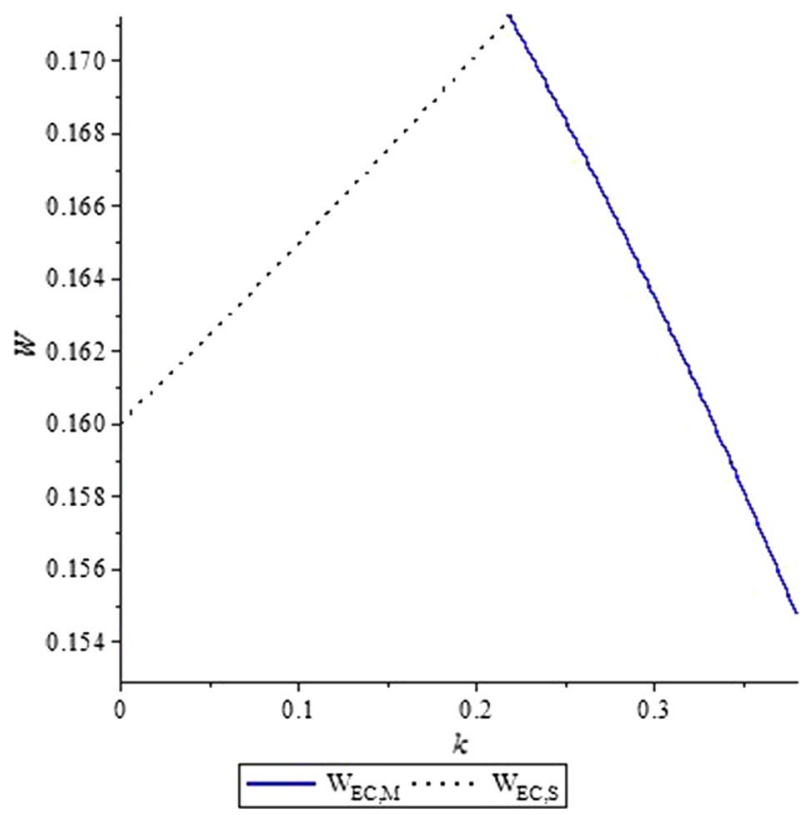

Fig. 3 Total welfare of exporting countries $\left(W_{\mathrm{EC}}\right)$ under the two SPNEs with different regimes: unique symmetric, S (i.e. policy/policy $(\mathrm{S}, \mathrm{S})$ ), and multiple asymmetric, M, (i.e. policy/no policy $(\mathrm{S}, \mathrm{FT})$ or no policy/policy (FT,S)), for a varying intensity of firms' social concerns (i.e. $0<k<0.382$ ) (window enlargement of Fig. 2). Legend: the graph is depicted for $a=1$

Remarks 2 and 3 are illustrated in Figs. 2 and 3. Moreover, by observing Remarks 1,2 and 3, it is natural to ask whether, taking account for the fact that for sufficiently low $k$, the case of subsidy policy is the SPNE and for sufficiently high $k$, the multiple asymmetric case is the SPNE, to have a high level of firms' social concerns is good or bad for both countries jointly considered. The answer is that with sufficiently high social concerns-implying a multiple asymmetric SPNE—-the total welfare is always higher than under free trade (as easily observed in Fig. 2). Hence, contrary to the case in which the trade policy is the SPNE-where there is always an incentive to a unilateral policy intervention and then at equilibrium both countries loseunder the mixed SPNE, there is always room for a coordination on one specific equilibrium, for instance-given that the gain for the country without trade policy is higher than the loss for the interventionist country with respect to the case in which also the latter country chooses "laissez-faire"- through side-payments between governments irrespective of which of them intervenes or abstains from intervention.

Note that this is a subtle argument: in fact, one could sustain that if governments are able to activate side-payments for supporting the asymmetric regime which require an agreement between them, it would be better to agree on the maximisation of the joint welfare (which is larger than that under asymmetric regime, as shown in Fig. 2): however, the asymmetric regime is a SPNE and, despite the fact that this is a jointly suboptimal regime for the exporter countries, is robust to cheating, while the 


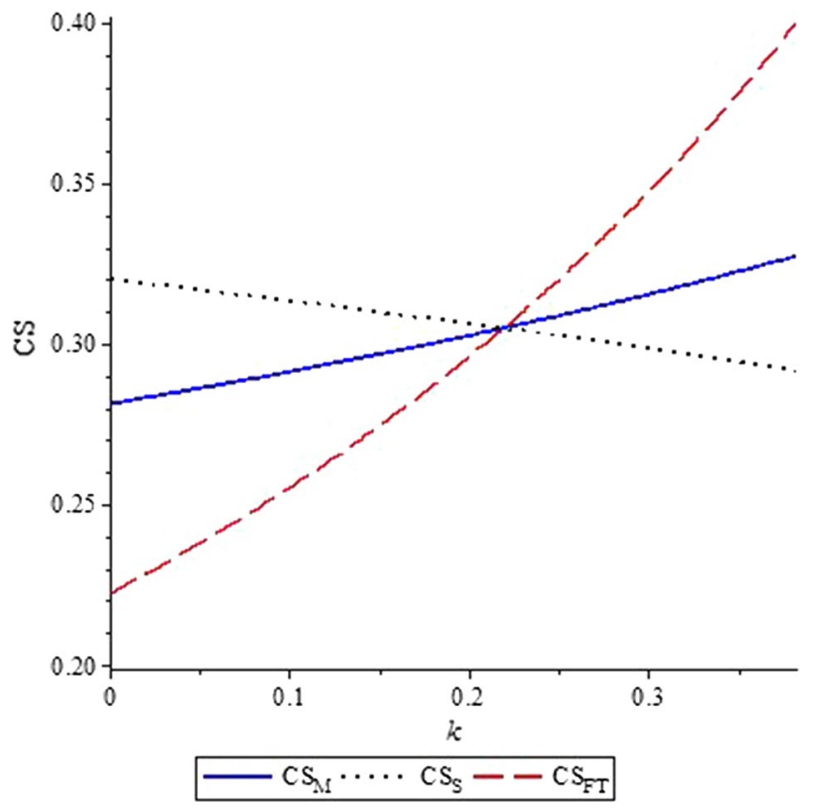

Fig. 4 Third market country's welfare (CS) under different regimes: unique symmetric, S (i.e. policy/policy, $(\mathrm{S}, \mathrm{S})$ ), and FT (i.e. free trade/free trade (FT,FT)), and multiple asymmetric, M, (i.e. policy/no policy $(\mathrm{S}, \mathrm{FT})$ or no policy/policy $(\mathrm{FT}, \mathrm{S}))$, for a varying intensity of firms' social concerns $($ i.e. $0<k<0.382)$. Legend: the graph is depicted for $a=1$

jointly optimal regime does not deter the incentive for one country to set a zero tax (i.e. to become a free trader).

\subsection{Welfare in importing countries and in the world}

Regarding the welfare of the consumers of the importing country as well as the welfare of the world as a whole, we remark the following:

Remark 4 While when the common public intervention is the SPNE, such policy regime is Pareto-efficient in terms of consumers' and world welfares, when the asymmetric public intervention is the SPNE, such an asymmetric policy regime is Pareto-inefficient because it would be dominated by the free-trade regime (see Figs. 4, 5).

Interestingly, the fact that when $k>k^{\circ \circ}$ consumers and world as a whole always would prefer a free-trade regime is in sharp contrast with the conventional belief of the Brander and Spencer' model in which they are the involuntary recipients of the exporter countries' policies. Moreover, we consider the role played by the CSR behaviour on the welfare in importing countries and in the world. This is important especially for what concerns consumers because 


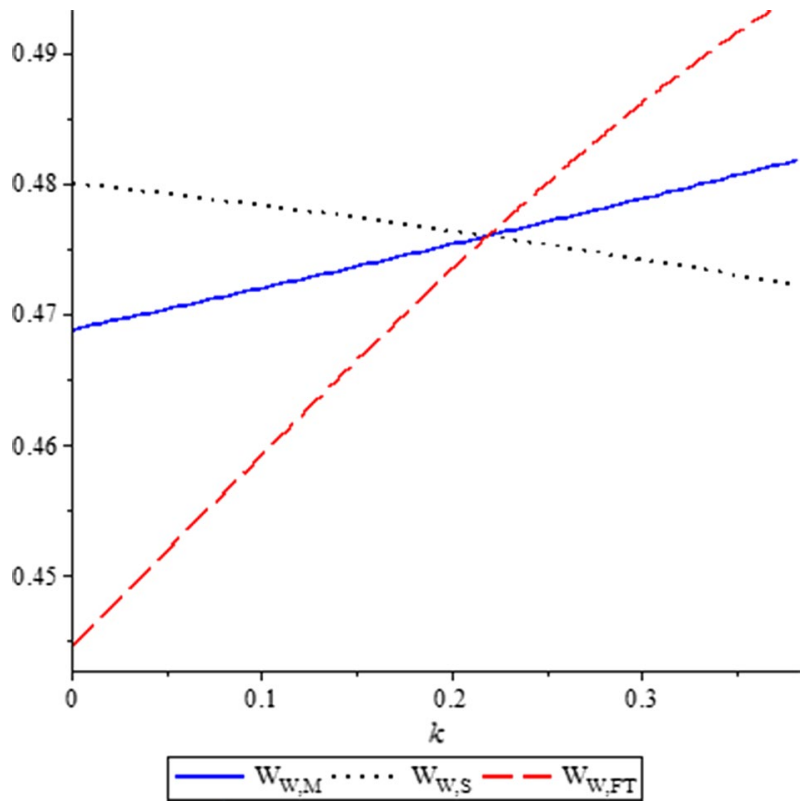

Fig. 5 Total world welfare $\left(W_{\mathrm{W}}\right)$ under different regimes: unique symmetric, $\mathrm{S}$ (i.e. policy/policy, $(\mathrm{S}, \mathrm{S})$ ), and FT (i.e. free trade/free trade (FT,FT)), and multiple asymmetric, M, (i.e. policy/no policy (S,FT) or no policy/policy (FT,S)), for a varying intensity of firms' social concerns (i.e. $0<k<0.382$ ). Legend: the graph is depicted for $a=1$

it is commonly retained that they would be better off if firms take into account their welfare.

Remark 5 In the regime in which both governments intervene, both the welfare of the third market country and the world welfare as a whole are reduced by the presence of socially responsible firms. By contrast, when the regime is asymmetric, such a presence is welfare-enhancing.

Therefore, taking into account the switch between equilibria occurring when firms' social concerns increase, consumers' and world welfares (1) are a U-shaped function of such concerns and (2) are smaller (resp. larger) when such concerns are sufficiently low (resp. high) (see Figs. 6, 7).

It is worth to note that despite firms care about the consumers' welfare, in equilibrium, the latter is decreasing for $k<k^{\circ \circ}$ and is lower than in the absence of firms' social concerns, except for extremely high values of $k$, regardless of whether the SPNE is S or M (the mixed one), as displayed in Fig. 5. However, given that the magnitude of the consumer surplus (which represents the welfare of the third country) is directly linked to the output produced by the exporting firms, Lemma 3 provides the rationale for this outcome. 


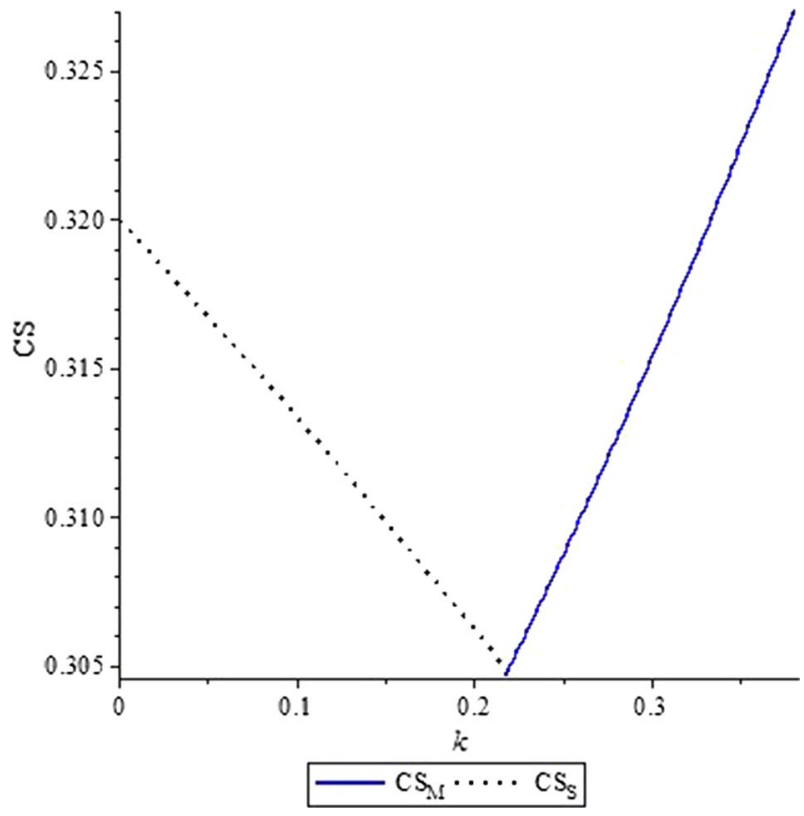

Fig. 6 Third market country's welfare under the two SPNEs with different regimes: unique symmetric, $\mathrm{S}$ (i.e. policy/policy $(\mathrm{S}, \mathrm{S})$ ), and multiple asymmetric, M, (i.e. policy/no policy (S,FT) or no policy/policy $(\mathrm{FT}, \mathrm{S})$ ), for a varying intensity of firms' social concerns (i.e. $0<k<0.382$ ) (window enlargement of Fig. 4). Legend: the graph is depicted for $a=1$

\section{Extensions: discussion}

In this section, we briefly discuss two extensions of the reference framework above presented.

First, the main model considers the weight attached to consumer surplus as exogenously given. Given that firms export to a third country, it can be plausible to assume that the level of CSR requested by the consumers in that country is taken as given for exporters. However, the recent literature on CSR has considered the case in which of the choice of the CSR activities is endogenous and represents a firm's strategic decision (see, for example, Fanti and Buccella 2017b, Supplement; Hino and Zennyo 2017; Planer-Friedrich and Sahm 2020). Therefore, we have investigated this model specification. Our preliminary results show that: (1) when both countries' governments intervene, numerical simulations (due to the complex analytical expressions) reveal that the optimal trade policy is a small export tax; (2) the social welfare under strategic trade policy is always higher than that under free trade; and (3) the social welfare with endogenous choice of CSR is always higher than the one with exogenous CSR for $k \leq k^{\circ} \approx 0.382$.

Second, we have also tested the model with the endogenous, strategic choice of the CSR level in which governments are not committed to the policy instruments, as described in Introduction. That is, governments fix the type (tax/subsidy) and size of the trade policy instrument only after firms have previously set the level of some 


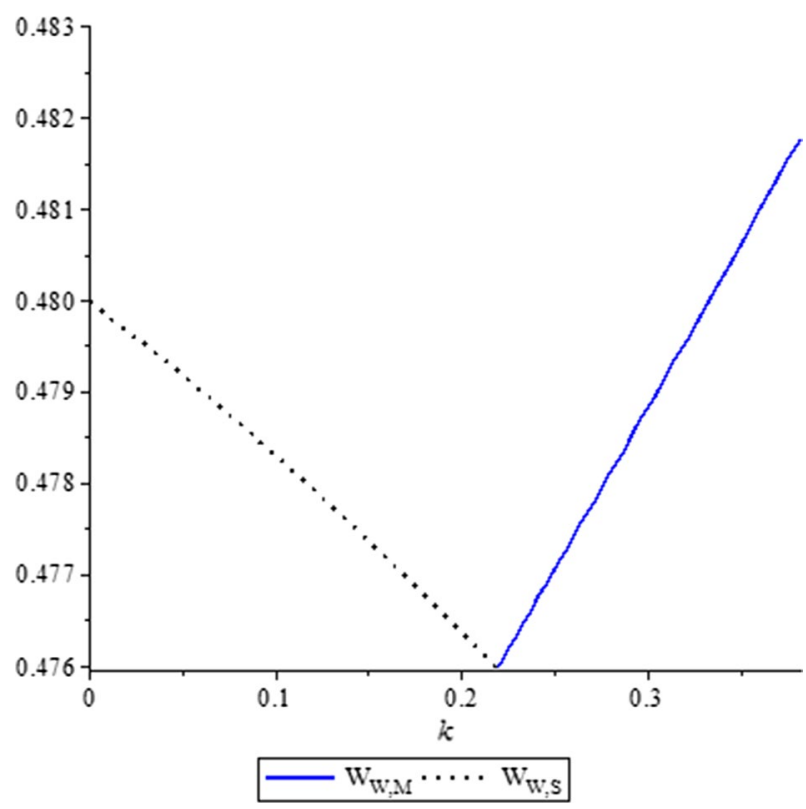

Fig. 7 Total world welfare $\left(W_{\mathrm{W}}\right)$ under the two SPNEs with different regimes: unique symmetric, $\mathrm{S}$ (i.e. policy/policy $(\mathrm{S}, \mathrm{S})$ ), and multiple asymmetric, M (i.e. policy/no policy (S,FT) or no policy/policy $(\mathrm{FT}, \mathrm{S})$ ), for a varying intensity of firms' social concerns (i.e. $0<k<0.382$ ) (window enlargement of Fig. 5). Legend: the graph is depicted for $a=1$

strategic variable, in the current context, the level of CSR engagement. In detail, at the pre-play, governments decide whether to intervene in trade policy. At the first stage of the game, firms strategically choose the degree of CSR engagement. At the second stage, governments set the trade policy tool. Finally, at the third stage, firms compete à la Cournot in the third market. Solving as usual the game by backward induction, the main results are as follows: (1) when both governments intervene in trade policy, firms do not engage in CSR; even more, if we relax the assumption that the parameter $k \in[0,1]$ and it becomes unconstrained, it is possible to show that it assumes negative values, i.e. firms engage in the so-called Corporate Social Irresponsible activities [see, for example, the special section "Corporate Social Responsibility and Irresponsibility" in the Journal of Business Research 66(10), edited by Murphy and Schlegelmilch (2013)]; and (2) as regards the strategic game played by national governments, two asymmetric equilibria arise in which the intervening government taxes export, partially confirming the results of the basic framework.

\section{Conclusions}

The issue of whether free trade or trade policies are better for the welfares of countries engaged in international trade is coming back high on the political agenda. For instance, while the Obama administration has been supporting bilateral free-trade 
agreements with Colombia, Panama and South Korea, advancing negotiations on two colossal regional accords such as the Asia-centred Trans-Pacific Partnership and the Transatlantic Trade and Investment Partnership with the European Union, the Trump administration has re-discussed these advancements reconsidering the possibility of introducing some trade policies. In this light, this study extends the traditional model of strategic trade policy in an export-rivalry context taking into account the recently increasing presence of the firms with corporate social responsibility behaviour. It is shown that the traditional results are significantly modified by such a presence.

The main results of the paper are as follows. First, the presence of sufficiently large socially concerned firms eliminates the Prisoner's dilemma structure of the governments' game of the traditional model, while multiple sub-game perfect equilibria in which one government taxes-so altering also the selection of the policy instrument-while the other one allows free trade, emerge. In particular, the social welfare of both countries in the latter asymmetric equilibrium is higher than that under free trade. Our findings suggest that a free-trade regime is always the less efficient policy in industries characterised by large social concerns. Moreover, we analyse the welfare effects of the presence of socially concerned firms interacting with strategic trade policies, regarding (1) exporting countries, (2) third market country, (3) world as a whole: it is shown that the welfares of consumers and world as a whole (resp. total welfare of producing countries) are a U-shaped (resp. an inverted U-shaped) function of the intensity of CSR concerns: this suggests that in some cases, rather unexpectedly, producing countries (resp. consumers) are beneficiated (resp. harmed) by raising firms' CSR “concerns". Therefore, it is worthwhile to remark that the conventional view that firms' social responsibility is consumer's welfare-improving is either challenged or confirmed in the export-rivalry context depending on the level of social responsibility is low or high, but in any case, the CSR behaviour is harmful for consumers for about eighty per cent of the admissible values of the CSR parameter.

As future lines of research, we can study how these findings change under heterogeneous and/or network goods, Bertrand competition and firms with asymmetric social concerns. Moreover, the present basic export-rivalry model could be extended for taking into account (1) the presence of domestic consumers in the producers' countries; (2) the sales' delegation to socially concerned managers by profit-maximising shareholders who own the firms; and (3) the policy activities of the government's importing third market for investigating whether and how the conventional findings of the international economics literature ${ }^{6}$ may be influenced by the increasing presence of firms' CSR behaviours. Furthermore, given that CSR can be a viable criterion for the targeting of industries, and given that, in our model, there is a preplay stage in which governments decide whether to subsidise or not, an interesting

\footnotetext{
6 In fact, it is worthwhile to recall that these extensions do not modify qualitatively the traditional results of the pioneering Brander and Spencer's model (1984b, pp. 10-13 and pp. 16-18). However, we believe that under CSR behaviours also the traditional results of these extensions could be changed and the present findings further enriched.
} 
future extension would be to consider the choice of which industry to subsidise (e.g. allowing for two industries that differ in their degree of CSR). Finally, in the current paper, policy only influences the output game of firms for given levels of CSR and has no effects on CSR. This may be well for a benchmark case-allowing for as direct a comparison as possible to the original strategic trade policy model, but enriching the way CSR affects firms' decisions (via costs/revenues and by endogenizing the owners' choice of $k$, for instance, in a bargain with stakeholders) would be a worthwhile extension to consider.

Acknowledgements We are extremely thankful to two anonymous referees for their valuable comments and suggestion which have helped us to improve substantially the quality and clarity of this work. The usual disclaimers apply.

Funding This study was not funded by any institution.

\section{Compliance with ethical standards}

Conflict of interest The authors declare that they have no conflict of interest.

Open Access This article is licensed under a Creative Commons Attribution 4.0 International License, which permits use, sharing, adaptation, distribution and reproduction in any medium or format, as long as you give appropriate credit to the original author(s) and the source, provide a link to the Creative Commons licence, and indicate if changes were made. The images or other third party material in this article are included in the article's Creative Commons licence, unless indicated otherwise in a credit line to the material. If material is not included in the article's Creative Commons licence and your intended use is not permitted by statutory regulation or exceeds the permitted use, you will need to obtain permission directly from the copyright holder. To view a copy of this licence, visit http://creativecommons.org/licen ses/by/4.0/.

\section{Appendix}

Proof of Lemma 1 Under strategic trade, from (9), it is directly evident that $q^{S, S}>0 \quad \forall k \in[0,1]$. On the other hand, it is straightforward to observe that the numerator of (10) is positive, and therefore, $\pi^{S, S} \geq 0$ iif $k \leq .5$. Moreover, $\frac{\partial^{2} W^{S}}{\partial q_{i}^{2}}=-2+k<0 \quad \forall k \in[0,1], \quad i=1,2$.Under free trade, inspection of (14) immediately reveals that $q^{\mathrm{FT}, \mathrm{FT}}>0 \quad \forall k \in[0,1]$. On the other hand, inspection of (15) shows that the numerator is positive, and therefore, $\pi^{\mathrm{FT}, \mathrm{FT}} \geq 0$ iif $k \leq .5$. Moreover, $\frac{\partial^{2} W^{\mathrm{FT}}}{\partial q_{i}^{2}}=-2+k<0 \quad \forall k \in[0,1], \quad i=1$, 2.Under unilateral strategic trade regime, from (19), one observes that $q_{1}^{S, \mathrm{FT}}>0$ if $k \in[0,1)$ and $q_{1}^{S, \mathrm{FT}}=0 \quad$ if $k=1$. On the other hand, analytical inspection of (20) shows that $q_{2}^{S, \mathrm{FT}}>0 \forall k \in[0,1]$.With regard to profits, inspection of (21) reveals that, $k \in[0,1]$, the numerator is positive, and therefore, $\pi_{1}^{S, \mathrm{FT}} \geq 0$ iif $k \leq \frac{3-\sqrt{5}}{2}=.328$, while $\quad \pi_{2}^{S \text {,FT }}>0$ if $k \in[0,1) \quad$ and $\quad \pi_{2}^{S, \mathrm{FT}}=0 \quad$ if $k=1$. Moreover, $\frac{\partial^{2} W_{i}^{\text {SFT }}}{\partial q_{i}^{2}}=\frac{\partial^{2} W_{j}^{S, F T}}{\partial q_{j}^{2}}=-2+k<0 \quad \forall k \in[0,1], i, j=1,2$.Therefore, the lowest value 
of the CSR parameter satisfying simultaneously all nonnegativity and second-order condition is $k \leq .328$.

Proof of Lemma 3 Part (1): by deriving (8) with respect to $k$, we obtain

$$
\frac{\partial s^{S}}{\partial k}=-\frac{a\left(23+4 k^{2}-20 k\right)}{(2 k-5)^{2}}<0 ;
$$

Part (2): by deriving (6) w.r.t $k$ and $s^{S}$, considering that at equilibrium $s_{i}=s_{j}=s^{S}$, we $\quad$ obtain $\frac{\partial q^{S}\left(s^{S}\right)}{\partial k}=\frac{2(a+s)}{(2 k-3)^{2}}>0, \quad \frac{\partial q^{S}\left(s^{S}\right)}{\partial s^{s}}=\frac{2-k}{3-2 k}>0 ; \quad$ however, $(+) \quad(+) \quad(-)$ since $\frac{\mathrm{d} q^{S}\left(s^{S}\right)}{\mathrm{d} k}=\frac{\partial q^{S}\left(s^{S}\right)}{\partial k}+\frac{\partial q^{S}\left(s^{S}\right)}{\partial s^{S}} \frac{\partial s^{S}}{\partial k}=-\frac{a}{(2 k-5)^{2}}<0$, part (2) is proved;

Part (3): by deriving (10) with respect to $k$, we obtain

$$
\frac{\partial \pi^{S}}{\partial k}=\frac{2(2-k)\left(2 k^{2}+11(1-k)\right)}{(2 k-5)^{3}}<0 .
$$

Proof of Lemma 4 The proof is obtained by deriving (10) with respect to $k$ at equilibrium the expression of the social welfare under strategic trade policy

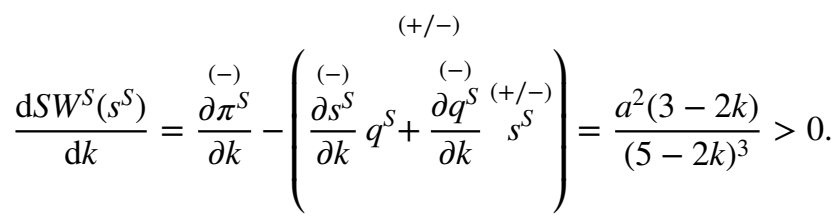

Proof of Lemma 5 By deriving (22) with respect to $k$, we obtain

$$
\begin{gathered}
\frac{\mathrm{d} \pi_{2 \mid s_{2}=0}\left(q_{1}, q_{2}\right)}{\mathrm{d} k}=\frac{\partial \pi_{2 \mid s_{2}=0}\left(q_{1}, q_{2}\right)}{\partial q_{1}} \frac{\stackrel{(-)}{\partial q_{1}}}{\partial k}+\frac{\partial \pi_{2 \mid s_{2}=0}\left(q_{1}, q_{2}\right)}{\partial q_{2}} \frac{\stackrel{(+)}{\partial q_{2}}}{\partial k} \\
=\frac{a^{2}\left(4+6 k^{2}-11 k-k^{3}\right)}{4(2-k)^{3}}>0 \quad(\text { if } k<0.486) .
\end{gathered}
$$

\section{References}

Baghdasaryan D, Žigić K (2010) Tariffs, market conduct, and government commitment: policy implications for developing countries. Econ Transit 18(1):91-122

Bagnoli M, Watts SG (2003) Selling to socially responsible consumers: competition and the private provision of public goods. J Econ Manag Strategy 12(3):419-445 
Bandyopadhyay S, Bandyopadhyay SC (1998) Monopoly unions and corporatism: implications for strategic trade policy. Int Econ J 12(4):1-22

Bandyopadhyay S, Bandyopadhyay SC (1999) Unionization and international market share rivalry: a paradox. Rev Int Econ 7(1):153-161

Bandyopadhyay S, Bandyopadhyay SC (2001) Efficient bargaining, welfare and strategic export policy. J Int Trade Econ Dev 10(2):133-149

Bandyopadhyay S, Bandyopadhyay SC, Park ES (2000) Unionized Bertrand duopoly and strategic export policy. Rev Int Econ 8(1):164-174

Baron D (2001) Private politics, corporate social responsibility, and integrated strategy. J Econ Manag Strategy 10:7-45

Baron D (2009) A positive theory of moral management, social pressure, and corporate social performance. J Econ Manag Strategy 18:7-43

Benabou R, Tirole J (2010) Individual and corporate social responsibility. Economica 77:1-19

Bennett J, Iossa E, Legrenzi G (2003) The role of commercial non-profit organizations in the provision of public services. Oxf Rev Econ Policy 19:335-347

Benz M (2005) Not for profit, but for satisfaction? Evidence on worker well-being in non-profit firms. Kyklos 58:155-176

Besley T, Ghatak M (2007) Retailing public goods: the economics of corporate social responsibility. J Public Econ 91(9):1645-1663

Brander JA (1995) Strategic trade policy. In: Grossman GM, Rogoff K (eds) Handbook of international economics, vol 3. Elsevier, Amsterdam, pp 1395-1455

Brander JA, Spencer BJ (1984a) Tariff protection and imperfect competition. In: Kierzkowski H (ed) Monopolistic competition and international trade. Oxford University Press, Oxford

Brander JA, Spencer BJ (1984b) Export subsidies and international market share rivalry, NBER, Working Paper No. 1464, September

Brander JA, Spencer BJ (1985) Export subsidies and international market share rivalry. J Int Econ 18:83-100

Campbell TJ, Eden L, Miller SR (2012) Multinationals and corporate social responsibility in host countries: does distance matter? J Int Bus Stud 43:84-106

Carmichael CM (1987) The control of export credit subsidies and its welfare consequences. J Int Econ 23(1-2):1-19

Chang Y-M, Chen H-Y, Wang LFS, Wu S-J (2014) Corporate social responsibility and international competition: a welfare analysis. Rev Int Econ 22:625-638

Chao AC, Lee J, Wang LFS (2016) Corporate social responsibility, trade liberalization and global welfare. In: Santos P (ed) Trade liberalization: global policies, Benefits and Economic Risks. Nova Science Publishers, New York, pp 25-36

Dixit AK (1987) Strategic aspects of trade policy. In: Bewley T (ed) Advances in economic theory. Cambridge University Press, Cambridge, pp 329-362

Eaton J, Grossman GM (1986) Optimal trade and industrial policy under oligopoly. Q J Econ 101:383-406

Etro F (2011) Endogenous market structures and strategic trade policy. Int Econ Rev 52(1):63-84

Fanti L, Buccella D (2016a) Passive unilateral cross-ownership and strategic trade policy. Econ E J 10(10):1-23

Fanti L, Buccella D (2016b) Strategic trade policy and union-firm bargaining agenda. J Int Trade Econ Dev 25(6):787-808

Fanti L, Buccella D (2017a) Strategic trade policy with bargaining over managerial contracts. Manag Decis Econ 38(8):1154-1161

Fanti L, Buccella D (2017b) Corporate social responsibility in a game-theoretic context. Economia e Politica Industriale, J Ind Bus Econ 44(3):371-390

Fortune (2015) Global 500. http://fortune.com/global500/. Accessed 29 Sept 2019

Goering GE (2007) The strategic use of managerial incentives in a non-profit firm mixed duopoly. Manag Decis Econ 28:83-91

Goering GE (2008) Welfare impacts of a non-profit firm in mixed commercial markets. Econ Syst 32:326-334

Grossman GM, Richardson JD (1985) Strategic U.S. trade policy: a survey of issues and early analyses. Special Paper No. 15, International Finance Section, Princeton University, April 1985

Helpman E, Krugman PR (1989) Trade policy and market structure. The MIT Press, Cambridge 
Hino Y, Zennyo Y (2017) Corporate social responsibility and strategic relationships. Int Rev Econ 64(3):231-244

Kopel M (2015) Price and quantity contracts in a mixed duopoly with a socially concerned firm. Manag Decis Econ 36(8):559-566

Kopel M, Brand B (2012) Socially responsible firms and endogenous choice of strategic incentives. Econ Model 29(3):982-989

Kotchen MJ (2006) Green markets and private provision of public goods. J Politcal Econ 114(4):816-834

KPMG (2011) KPMG survey of corporate responsibility reporting 2013. https://www.kpmg.com/PT/pt/ IssuesAndInsights/Documents/corporateresponsibility2011.pdf. Accessed 29 Sept 2019

KPMG (2015) Currents of change: KPMG survey of corporate responsibility reporting 2015. http://www. kpmg.com/cn/en/issuesandinsights/articlespublications/pages/kpmg-survey-of-corporate-responsibi lity-reporting-2015-o-201511.aspx. Accessed 29 Sept 2019

Krugman P (1984) Import protection as export promotion. In: Kierzkowski H (ed) Monopolistic competition and international trade. Oxford University Press, Oxford

Krugman P (ed) (1986) Strategic trade policy and the new international economics. The MIT Press, Cambridge

Lambertini L, Tampieri A (2012) Corporate social responsibility and firms ability to collude. In: Boubaker S, Nguyen D (eds) Board directors and corporate social responsibility. Palgrave Macmillan, London

Lambertini L, Tampieri A (2015) Incentives, performance and desirability of socially responsible firms in a Cournot oligopoly. Econ Model 50(C):40-48

Leahy D, Neary JP (1997) Public policy towards R\&D in oligopolistic industries. Am Econ Rev 87(4):642-662

Manasakis C, Mitrokostas E, Petrakis E (2014) Strategic corporate social responsibility activities and corporate governance in imperfectly competitive markets. Manag Decis Econ 35:460-473

Murphy PE, Schlegelmilch BB (2013) Corporate social responsibility and irresponsibility. J Bus Res 66(10):1807-1963

Neary JP, Leahy D (2000) Strategic trade and industrial policy towards dynamic oligopolies. Econ J 110(463):484-508

Planer-Friedrich L, Sahm M (2020) Strategic corporate social responsibility, imperfect competition, and market concentration. J Econ 129:79-101

Porter ME, Kramer MR (2006) Strategy and society: the link between corporate social responsibility and competitive advantage. Harv Bus Rev 84(12):78-92

Schiff J, Weisbrod B (1991) Competition between for-profit and nonprofit organizations in commercial markets. Ann Public Coop Econ 62:619-639

Scott RE, Glass E, (2016) Trans-Pacific Partnership, currency manipulation, trade and jobs. Briefing Paper \#420, Economic Policy Institute. https://www.epi.org/publication/trans-pacific-partnershi p-currency-manipulation-trade-and-jobs/. Accessed 12 Oct 2019

Spencer BJ (1986) What should trade policy target? In: Krugman P (ed) Strategic trade policy and the new international economics. The MIT Press, Cambridge

Spencer BJ, Brander JA (2008) Strategic trade policy. In: Durlauf SN, Blume LE (eds) The new Palgrave dictionary of economics, 2nd edn. Palgrave Macmillan, London

Wang LFS, Wang YC, Zhao L (2012) Tariff policy and welfare in an international duopoly with consumer-friendly initiative. Bull Econ Res 64:56-64

Žigić K (2011) Does 'non-committed' government always generate lower social welfare than its 'committed' counter-part? strategic trade policy when consumer surplus matters. J Comp Econ 39(4):533-556

Publisher's Note Springer Nature remains neutral with regard to jurisdictional claims in published maps and institutional affiliations. 